\title{
Pituitary apoplexy: pathophysiology, diagnosis and management
}

Andrea Glezer', Marcello D. Bronstein'

\begin{abstract}
Pituitary apoplexy is characterized by sudden increase in pituitary gland volume secondary to ischemia and/or necrosis, usually in a pituitary adenoma. Most cases occur during the $5^{\text {th }}$ decade of life, predominantly in males and in previously unknown clinically non-functioning pituitary adenomas. There are some predisposing factors as arterial hypertension, anticoagulant therapy and major surgery. Clinical picture comprises headache, visual impairment, cranial nerve palsies and hypopituitarism. Most cases improve with both surgical and expectant management and the best approach in the acute phase is still controversial. Surgery, usually by transsphenoidal route, is indicated if consciousness and/or vision are impaired, despite glucocorticoid replacement and electrolyte support. Pituitary function is impaired in most patients before apoplexy and ACTH deficiency is common, which makes glucocorticoid replacement needed in most cases. Pituitary deficiencies, once established, usually do not recover, regardless the treatment. Sellar imaging and endocrinological function must be periodic reevaluated. Arch Endocrinol Metab. 2015;59(3):259-64
\end{abstract}

Keywords

Pituitary; apoplexy; pituitary adenoma; hypopituitarism
${ }^{1}$ Neuroendocrine Unit, Division of Endocrinology and Metabolism, Hospital das Clinicas, University of Sao Paulo Medical School (HCFMUSP), São Paulo, SP, Brazil

Correspondence to:

Marcello D. Bronstein

Rua Enéas de Carvalho Aguiar, 155, $8^{\circ}$ andar, bloco 3

05403-000 - São Paulo, SP, Brazil

mdbronstein@uol.com.br

Received on May/29/2015 Accepted on May/29/2015

DOI: 10.1590/2359-3997000000047

\section{INTRODUCTION}

$\mathrm{P}$ ituitary apoplexy (PA) is characterized by acute infarction and/or hemorrhage of the pituitary gland. The term pituitary apoplexy was coined by Brougham in 1950, and the first index case was, in fact, described by Bailey, in 1898 (1). Routine imaging and histopathological evaluation may detect asymptomatic pituitary hemorrhage, known as subclinical apoplexy, and is much more frequent then PA (2). Apoplexy means "sudden attack" in Greek, and, as a result, an abrupt increase of tissue volume within the sellar region can cause headache, visual impairment, cranial nerve palsies and, even, impairment of consciousness, besides causing pituitary hormone deficiencies as ACTH. In most cases, apoplexy involves a previously unrecognized pituitary adenoma. Although rare, the condition must be recognized and properly treated, as it may in fact be life threatening.

\section{EPIDEMIOLOGY}

PA is rare, with an estimated prevalence $\sim 6.2$ cases per 100,000 inhabitants (3) and incidence of 0.17 episodes per 100,000 person-years (4). PA occurs in $0.6 \%$ to $10 \%$ of treated pituitary adenomas (5) and its risk in non-functioning pituitary adenomas is $0.2-0.6$ events per 100 person-year $(6,7)$.

Usually, PA occurs in the fifth or sixth decade, with a discrete preponderance in males. Jankoswski and cols. reviewed PA in adolescents, a very rare entity (8). Amongst $60 \%$ to $80 \%$ of cases, pituitary adenoma was not a previously known condition (2). Macroadenomas, especially non-functioning and prolactinomas, are most susceptible to apoplexy, nevertheless apoplexy in microadenomas has been reported (9). Cavernous sinus invasion may be a prognostic factor associated with PA (10).

Although PA usually occurs in adenomas; it has also been described in non-adenomatous lesions including hypophysitis $(11,12)$, metastasis to pituitary, especially from renal cell carcinoma (13), craniopharyngioma, Rathke's cleft cyst and sellar tuberculoma (14).

\section{PHYSIOPATHOLOGY}

The precise pathophysiology is not completely understood. However, a proposed hypothesis involves tumor vascular occlusion due to tumor growth, tumor blood flux reduction and tumoral abnormal (immature) vascularization. VEGF mRNA may be increased in pitui- 
tary tumors, especially in non-functioning pituitary adenomas, which could be related to an abnormal vascularization (15). As the usual trigger is not identified, vasculopathy may occur in apoplectic tumors. Four categories of triggering factors have been suggested (16):

1. Vascular flux reduction: surgery, specially cardiac surgery, radiotherapy, post spinal anesthesia.

2. Acute increase in blood flow: physical activity, systemic hypertension.

3. Pituitary stimulation: provocative pituitary tests, specially TRH, GnRH analogues use.

4. Coagulation disturbs: thrombocytopenia, anticoagulation.

Other risk factors include pregnancy, diabetes mellitus, sickle cell anemia, estrogen replacement, dopamine agonist therapy, lymphocytic leukemia and head trauma.

Precipitating factors can be identified in about $40 \%$ of PA cases, with arterial hypertension the most frequent (2). Other common risk factors include anticoagulant therapy, and new oral anticoagulants (17).

Dopamine agonists are considered a risk factor for PA. As they are largely used in prolactinomas, apoplexy was more frequently reported in macroprolactinomas, and within the first year and a half of treatment (18). In three series with symptomatic cases, the ratio apoplexy/therapy varied between 1.2 to $6.67 \%$. More recently, in 368 patients with prolactinomas: hemorrhage in imaging was depicted in $6.8 \%$ and symptomatic PA was observed in only three patients. Macroprolactinoma and female gender were more associated with hemorrhage (19). There are some case reports of PA related to medical treatment in acromegaly: three cases on octreotide and four cases receiving lanreotide (20).

Through 2012, 34 cases of PA occurring after endocrine tests were described, with $93 \%$ macroadenomas with extrasellar extension. Most cases were associated with TRH and GnRH stimulation. Mechanisms are not clear; however increased norepinephrine levels by TRH may cause vasospasm; and an increase in tumor cells metabolic activity may be induced by $\mathrm{GnRH}(2 \mathrm{l})$.

In a review of PA following $\mathrm{GnRH}$ analog administration, of 15 cases, 14 were male and eigth presented within four hours after the first injection. GnRH antagonist also used for prostate cancer may be a safer alternative considering PA risk in patients harboring pituitary adenomas (22). Other uncommon risk factors as high altitude (23) and hemorrhagic dengue (24) were recently described.

Although major surgery, especially cardiac surgery, is associated with PA, minor laparoscopic surgery has also been described in the PA context (25).

Pregnancy is a risk factor for PA, probably due to an increased pituitary volume secondary to lactotroph hyperplasia, which returns to normal six months post-partum, and also due to increased pituitary blood flow induced by estrogens. Piantanida and cols. reviewed PA during pregnancy: ten prolactinomas, two GH-secreting adenomas, four non-functioning pituitary adenomas and one with no information, most were surgically treated (26).

And finally, socioeconomic factors such as lack of health insurance, had been associated with PA (27).

Mechanisms explaining clinical manifestation of PA are detailed in figure 1 .

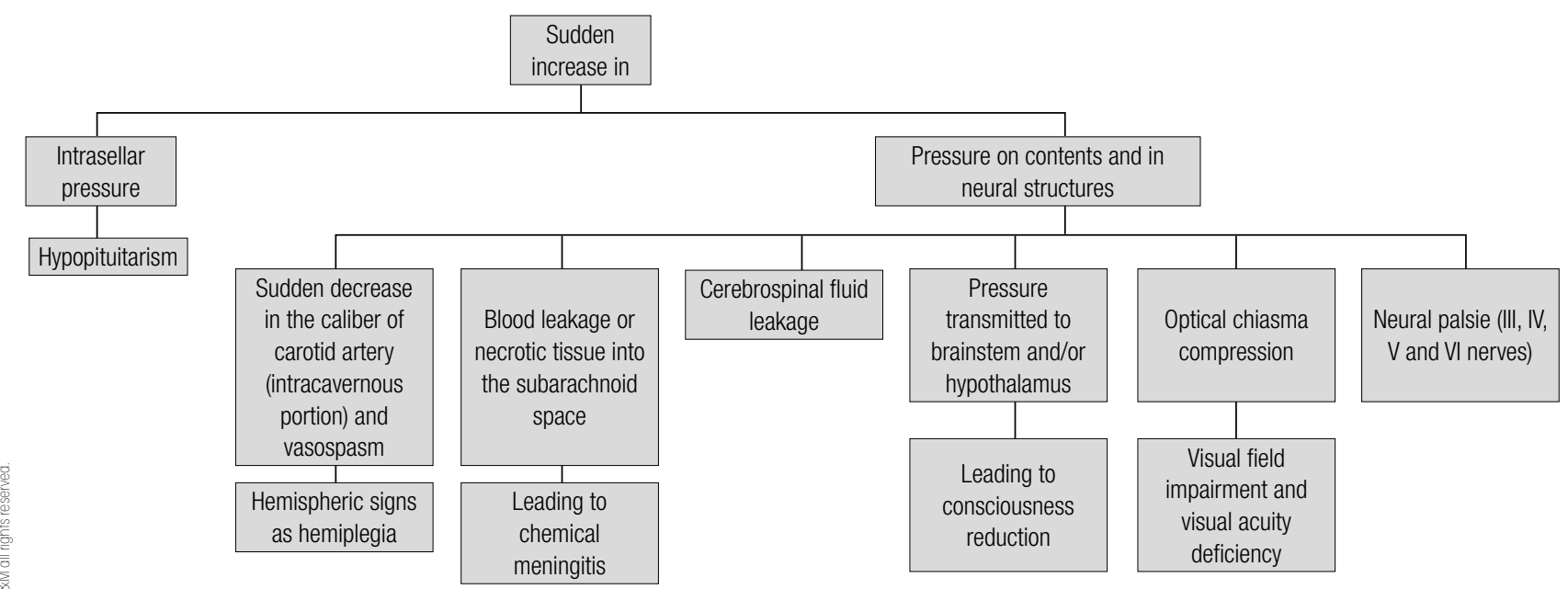

Figure 1. Mechanisms contributing to the clinical picture in pituitary apoplexy (5). 


\section{DIAGNOSIS AND MANAGEMENT}

Classically, symptoms evolve from hours to two days after the onset of apoplexy, although a subacute course is described (28). Most patients complain of headache, visual defects and ophtalmoplegia. A high degree of suspicion is needed to make the clinical diagnosis as most patients do not have a previous history of known pituitary adenoma. Common differential diagnoses are subarachnoid hemorrhage and bacterial meningitis; other conditions include: midbrain infarction, cavernous sinus thrombosis, migraine and hemorrhagic infarction in a Rathke's cyst and aneurysms. It is important to stress that pituitary adenomas co-exist with cerebral aneurysms at a rate of $7.4 \%$.

Eight series in the literature include more than ten patients and are detailed in table 1 .

Brain imaging is required to identify a pituitary lesion. Although cranial computed tomography (CT) scan is easier to obtain, it is less sensitive for diagnosis of pituitary lesions. In a retrospective series, a CT scan identified pituitary tumor in $93 \%$ and hemorrhage in $21 \%$ of cases, whereas MRI identified $100 \%$ and $88 \%$ of cases, respectively (29).

Table 1. Series of patients with pituitary apoplexy

\begin{tabular}{|c|c|c|c|c|c|c|c|c|}
\hline & $\begin{array}{l}\text { Bills DC } \\
\text { and cols., } \\
1993(32)\end{array}$ & $\begin{array}{l}\text { MacCagnan P } \\
\text { and cols., } \\
1995(33)\end{array}$ & $\begin{array}{l}\text { Randeva HS } \\
\text { and cols., } \\
1999(34)\end{array}$ & $\begin{array}{c}\text { Ayuk J } \\
\text { and cols., } \\
2004(30)\end{array}$ & $\begin{array}{l}\text { Lubina and } \\
\text { cols., 2005 } \\
\text { (35) }\end{array}$ & $\begin{array}{l}\text { Bujawansa } \\
\text { and cols., } \\
2014(36)\end{array}$ & $\begin{array}{l}\text { Jho and cols., } \\
2014 \text { (37) }\end{array}$ & $\begin{array}{c}\text { Singh and } \\
\text { cols., } 2015(38)\end{array}$ \\
\hline \multicolumn{9}{|l|}{ Patients } \\
\hline N & 37 & 12 & 35 & 33 & 40 & 55 & 109 & 87 \\
\hline Male/female & $25 / 12$ & $7 / 5$ & $21 / 14$ & $20 / 13$ & $27 / 13$ & & $69 / 40$ & $57 / 30$ \\
\hline Mean age (yr) & 56.6 & 43 & 49.8 & 52 & 51.2 & 52.4 & 51 & 50.9 \\
\hline Operated & 36 & 5 & 31 & 15 & 34 & 22 & 101 & 61 \\
\hline \multicolumn{9}{|l|}{ Symptoms \% } \\
\hline Headache & 95 & 100 & 97 & 97 & 63 & 87 & 87 & 89.7 \\
\hline Visual defects & 64 & 66 & 71 & 82 & 61 & 36 & 39.4 & 33.3 \\
\hline Ophtalmoplegia & 78 & 83 & 69 & 46 & 40 & 47.2 & 35.8 & 39 \\
\hline Predisposing factors & & $\begin{array}{c}2 \text { with diabetes } \\
\text { mellitus, one on } \\
\text { bromocriptine, } \\
\text { one with a } \\
\text { major surgery, } \\
\text { one with } \\
\text { pituitary } \\
\text { radiotherapy, } \\
\text { one with arterial } \\
\text { hypertension, } \\
\text { one with } \\
\text { chronic renal } \\
\text { failure }\end{array}$ & $\begin{array}{c}26 \% \text { arterial } \\
\text { hypertension, } \\
14 \% \\
\text { contraceptive } \\
\text { oral pills, } 9 \% \\
\text { on aspirin } \\
\text { therapy }\end{array}$ & $\begin{array}{l}33 \% \text { arterial } \\
\text { hypertension }\end{array}$ & $\begin{array}{c}2 \text { head trauma, } \\
2 \text { anticoagulant } \\
\text { treatment, } 1 \\
\text { general } \\
\text { anesthesia }\end{array}$ & $\begin{array}{c}20 \% \text { arterial } \\
\text { hypertension, } \\
\text { three on } \\
\text { warfarin }\end{array}$ & & $\begin{array}{c}39 \% \text { arterial } \\
\text { hypertension, } \\
12.6 \% \text { diabetes } \\
\text { mellitus, } 10.3 \% \\
\text { on anticoagulant } \\
\text { therapy, one } \\
\text { pregnant and } \\
\text { three in post } \\
\text { partum period, } \\
\text { two after major } \\
\text { surgery }\end{array}$ \\
\hline \multicolumn{9}{|l|}{ Adenoma type\% } \\
\hline NFPA & 52 & - & 61 & 24 & 63 & 82 & & 29.5 \\
\hline Prolactinoma & 17 & - & 5.5 & - & 31 & 11.5 & & 13.2 \\
\hline $\begin{array}{l}\text { Visual field deficits/ } \\
\text { visual acuity } \\
\text { recovered after } \\
\text { surgery }\end{array}$ & $95 \% / 88 \%$ & $62 \%$ & $86 \% / 76 \%$ & $57 \% / \mathrm{NA}$ & $81 \% / \mathrm{NA}$ & $80 \% / \mathrm{NA}$ & & $93.3 \% / 94.4 \%$ \\
\hline \multicolumn{9}{|l|}{$\begin{array}{l}\text { Pituitary hormone } \\
\text { deficiency } \%\end{array}$} \\
\hline ACTH & 82 & 25 & 58 & 78 & 40 & 72.7 & & 60 \\
\hline TSH & 89 & 33 & 43 & 60 & 54 & 52.7 & & 62.7 \\
\hline $\mathrm{LH} / \mathrm{FSH}$ & 64 & 41 & 43 & 75 & 79 & 77 & & 63.6 \\
\hline Diabetes insipidus & 11 & - & 6 & 6 & 8 & 3 & & 23 \\
\hline
\end{tabular}

NA: not avaiable; NFPA: nonfunctioning pituitary adenoma. 
Hormonal pituitary evaluation is required to diagnose secreting pituitary adenomas including prolactinoma, somatotropinoma and corticotropinoma, as well as hypopituitarism. As ACTH deficiency is life-threatening condition, glucocorticoid replacement is recommended and a supraphysiological dose is indicated to control edema on parasellar structures: dexamethasone 8 to $16 \mathrm{mg}$ per day or hydrocortisone $50 \mathrm{mg}$ intravenously every 6 hours (30). Anterior pituitary deficiencies occur in nearly $80 \%$ of patients: ACTH in up to $70 \%$, TSH in $50 \%$ and gonadotrophin in $75 \%$ of cases $(14,28,31)$. Patients with low levels of prolactin exhibit a lower probability of pituitary function recovery after surgery. Hyponatremia, observed in up to $40 \%$ of cases, can be secondary to hypocortisolism or inappropriate antidiuretic hormone secretion. Transient diabetes insipidus is rarely encountered (2).

The first intervention after PA diagnosis is hemodynamic stabilization, correction of electrolyte disturbances and corticosteroid administration. Most PA cases improve with both surgical and expectant management and the most appropriate approach in the acute phase is controversial (28). Although guidelines, as the one from UK, proposed an algorithm for PA management, a randomized trial comparing both strategies is needed for strong evidence $(2,29)$. However, seems intuitive that surgery, usually by the transsphenoidal route, is indicated if consciousness and/or vision are impaired, despite glucocorticoid replacement and electrolyte support. Recovery of visual fields and acuity impairment is more readily obtained with surgical decompression, usually within seven days after the apoplectic event (2). Ophtalmoplegia can resolve spontaneously, with or without surgery. Pituitary function is impaired in most patients before apoplexy and ACTH deficiency is common, which makes glucocorticoid replacement needed in most cases. Pituitary deficiencies, once established, usually do not recover, regardless the treatment $(29,32)$.

The decision to manage conservatively or surgically should be made by experts from a multidisciplinary team (2). Visual impairment and neurological deterioration not improving with clinical management are indications of surgical intervention, with a higher rate of visual improvement if performed within the first seven days of symptom. In a department in UK, PA score was calculated using visual acuity, visual defects, cranial nerve palsies and Glasgow Coma Scale, ranging from 0 to 10 , and a score equal and more than 4 appeared to in- fluence the management towards surgery (2). Jho and cols. proposed another score for PA: grade 1 asymptomatic, grade 2 symptoms due to endocrinopathy, grade 3 for headache, grade 4 ocular paresis and grade 5 for visual deficits or a low Glasgow Coma Scale. The authors evaluated 109 cases of PA concluding that their proposed score considering clinical and imaging characteristics is useful in identifying patients who should be submitted to surgery (grade 5). They also observed that prolactinomas, hemorrhagic Rathke cleft cysts and the presence of significant clinical comorbidities favor medical treatment. The major study bias is that most patients (101) were treated surgically (37).

Long-term endocrine and imaging follow-up is required for patients with pituitary apoplexy.

\section{Imaging follow-up}

Within the first three days, hyperdensity is depicted in intrasellar and suprasellar regions in an uncontrasted CT scan. It is difficult to differentiate PA from parasellar aneurysm using CT, and MRI is more specific. As hyperdensity in the subacute and chronic phases of hemorrhage fades, CT sensitivity to diagnose PA diminishes and the lesion could be misdiagnosed as an abscess or cystic degeneration. In contrast, CT is superior during the first three hours after apoplexy. Usually in the first week, an isointensity on $\mathrm{T}_{1}$-weighted scans and a hypointensity on $\mathrm{T}_{2}$-weighted images can be observed with MRI. Sphenoid sinus mucosa thickening is suggestive of PA in the early hours. Subacutely (between $7^{\text {th }}$ and $14^{\text {th }}$ days), there is focal or heterogeneous increased signal on $\mathrm{T}_{1}$-weighted scans, and a progressive increase in signal on $\mathrm{T}_{2}$-weighted images. After gadolinium, a peripheral enhancement is represented by a thin peripheral rim. In the chronic phase, there is signal increase in both $\mathrm{T}_{1}$ and $\mathrm{T}_{2}$ weighted images $(39,40)$.

Fluid debris levels in a pituitary mass, hyperintense on $\mathrm{Tl}$, corresponding to extracellular meta-hemoglobin and the lower layer iso-hypointense on $\mathrm{Tl}$ corresponding to red blood remnants sediment, is suggestive of late subacute hemorrhage. Table 2 summarizes MRI changes in PA by time, for hemorrhagic findings. Necrosis imaging can be detected as hypodensity by CT and hypointense on $\mathrm{T} 1$ and hyperintense on $\mathrm{T} 2$ on MRI (29).

Using serial sellar MRI, tumor reduction and even disappearance is common, avoiding additional treat- 
ment in most cases. In the long-term, imaging shows empty sella, partially empty sella or even normal pituitary. However, tumor recurrence has been described in $6 \%$ of patients and this risk is not increased after conservative management $(31)$.

A sellar MRI depicting signs of an acute PA is depicted in figure 2 and a subacute PA in a patient with acromegaly is depicted in figure 3. After apoplexy, serum GH and IGF-1 levels were normal.

MRI scan can be performed three to six months after apoplexy, annually in the following five years and then, biannual (2).

Table 2. MRl findings in pituitary apoplexy

\begin{tabular}{|c|c|c|c|}
\hline $\begin{array}{c}\text { Pituitary } \\
\text { apoplexy phase }\end{array}$ & $\begin{array}{c}\text { Acute } \\
\text { (until } 7^{\text {th }} \text { day) }\end{array}$ & $\begin{array}{c}\text { Subacute } \\
\text { ( } 7^{\text {th }} \text { to } 14^{\text {th }} \text { day) }\end{array}$ & $\begin{array}{l}\text { Chronic (more } \\
\text { than } 15 \text { days) }\end{array}$ \\
\hline $\begin{array}{l}\mathrm{T}_{1} \text {-weighted } \\
\text { scans }\end{array}$ & Isointense & Increase in signal & Hyperintense \\
\hline $\begin{array}{l}\mathrm{T}_{2} \text {-weighted } \\
\text { scans }\end{array}$ & Hypointense & $\begin{array}{c}\text { Hypo or } \\
\text { hyperintense }\end{array}$ & Hyperintense \\
\hline
\end{tabular}
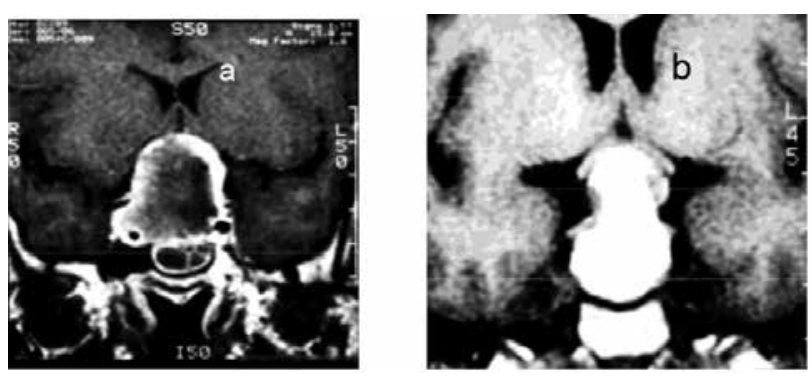

Figure 2. Sellar MRI depicting signs of a acute pituitary apoplexy in two patients: (a): a hyperintense lesion impinging optical chiasm in noncontrasted $\mathrm{T}_{1}$-weighted scan and $(\mathbf{b})$ : a peripheral rim in a contrasted $\mathrm{T}_{1}$-weighted scan.
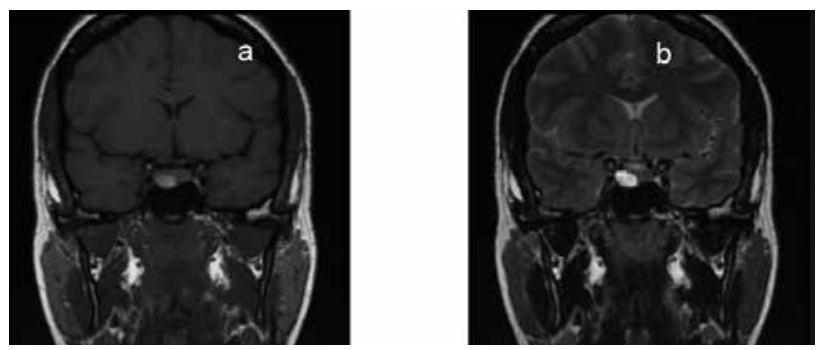

Figure 3. Sellar MRI depicting signs of a subacute pituitary apoplexy: a hyperintense lesion in seeing in $\mathrm{T}_{1}-(\mathbf{a})$ and $\mathrm{T}_{2}-(\mathbf{b})$ weighted scans.

\section{Endocrinological follow-up}

Appropriate hormone replacement is required. For functioning pituitary adenomas, hormonal secretion must be also evaluated: hormonal levels could be low, normal or remain high after apoplexy. Long-term follow-up is indicated to identify tumor recurrence. A reevaluation four to eight weeks after apoplexy is recommended (2).

\section{CONCLUSION}

PA evolves in hours to two days and the condition includes acute headache, meningismus, nausea and vomiting, visual disturbances, blindness, ocular palsies, and decreased level of consciousness. There is a slight male to female preponderance with a mean age of $\sim 50$ years. All pituitary adenoma types are at risk of apoplexy, although in some series most tumors were nonfunctioning. Cranial magnetic resonance imaging (MRI) is crucial for the diagnosis. Apoplexy pathophysiology remains uncertain and could be associated with trauma, anticoagulation therapy, arterial hypertension, cardiac and other systemic surgeries and dynamic pituitary function tests. Treatment consists of substitution therapy with steroids and sellar decompression by transsphenoidal surgery in severe cases.

\section{REFERENCES}

1. Rolih CA, Ober KP. Pituitary apoplexy. Endocrinol Metabol North Am. 1993;22:291-302.

2. Rajasekaran S, Vanderpump M, Baldeweg S, Drake W, Reddy N, Lanyon $\mathrm{M}$, et al. UK guidelines for the management of pituitary apoplexy. Clin Endocrinol (Oxf). 2011;74(1):9-20.

3. Fernandez A, Karavitaki N, Wass JA. Prevalence of pituitary adenomas: a community-based, cross-sectional study in Banbury. Clin Endocrinol. 2010;72:377-82.

4. Raappana A, Koivukangas J, Ebeing T, Pirilä T. Incidence of pituitary adenomas in Northern Finland in 1992-2007. J Clin Endocrinolol Metab. 2010;95:4268-75.

5. Nawar RN, AbdelMannan D, Selman WR, Arafah BM. Pituitary tumor apoplexy: a review. J Intensive Care. 2008;23:75-90.

6. Fernández-Balsells MM, Murad MH, Barwise A, Gallegos-Orozco JF, Paul A, Lane MA, et al. Natural history of nonfunctioning pituitary adenomas and incidentalomas: a systematic review and metaanalysis. J Clin Endocrinol Metabol. 2011;96:905-12.

7. Sivakumar W, Chamoun R, Nguyen V, Couldwell WT. Incidental pituitary adenomas. Neurosurg Focus. 2011;31(6):E18.

8. Jankoswski PP, Crawford JR, Khanna P, Malicki DM, Ciacci JD, Levy ML. Pituitary tumor apoplexy in adolescentes. Word Neurosurg. 2015;83(4):644-5.

9. Randall BR, Couldwell WT. Apoplexy in pituitary microadenomas. Neurochir. 2010;152:1737-40.

10. Cinar N, Tekinel Y, Dagdelen S, Oruckaptan H, Soylemezoglu F, Erbas T. Cavernous sinus invasion might be a risk factor for apoplexy. Pituitary. 2013;16(4):483-9.

11. Dan NG, Feiner RI, Houang MT, Turner JJ. Pituitary apoplexy in association with lymphocytic hypophysitis. J Clin Neurosci. 2002;9:577-80.

12. Husain Q, Zouzias A, Kanumuri VV, Eloy JA, Liu JK. Idiopathic granulomatous hypophysitis presenting as pituitary apoplexy. $\mathrm{J}$ Clin Neurosc. 2014;21:510-2. 
13. Chhiber SS, Bhat AR, Khan SH, Wani MA, Ramzan AU, Kirmani $A R$, et al. Apoplexy in sellar metastasis: a case report and review of literature. Turk Neurosurg. 2011;21(2):230-4.

14. Capatina C, Inder W, Karavitaki N, Wass JA. Management of endocrine disease: pituitary tumour apoplexy. Eur J Endocrinol. 2015;172(5):R179-90.

15. Möller-Goede DL, Brändle M, Landau K, Bernays RL, Schmid C. Pituitary apoplexy: re-evaluation of risk factors for bleeding into pituitary adenomas and impact on outcome. Eur $\mathrm{J}$ Endocrinol. 2011;164(1):37-43.

16. Proust F, Hannequin D, Bellow F, Langlois $O$, Tadié M, Creissard $P$, et al. Stress-induced pituitary apoplexy in 2 cases. Neurochirurgie. 1995;41(5):372-6.

17. Doglietto F, Costi E, Villaret AB, Mardighian D, Fontanella MM, Giustina A. New oral anticoagulants and pituitary apoplexy. Pituitary 2014 Nov 23. [Epub ahead of print]).

18. Carija R, Vucina D. Frequency of pituitary tumor apoplexy during treatment of prolactinomas with dopamine agonists: a systematic review. CNS Neurol Disord Drug Targets. 2012;11(8):1012-4.

19. Sarwar KN, Huda MS, Van de Velde V, Hopkins L, Luck S, Preston R, et al. The prevalence and natural history of pituitary hemorrhage in prolactinoma. J Clin Endocrinol Metab. 2013;98(6):2362-7.

20. Bakiri F, Herrera J, Riestra M, Perrichot O, Pertierra J, Bruno OD, et al. Pituitary apoplexy after somatostatin analogue administration: coincidental or causative? Clin Endocrinol (Oxf). 2014;81(3):471-3.

21. Yamamoto T, Yano S, Kuroda J, Hasegawa Y, Hide T, Kuratsu J. Pituitary apoplexy associated with endocrine stimulation test: endocrine stimulation test, treatment, and outcome. Case Rep Endocrinol. 2012;2012:826901.

22. SasagawaY, Tachibana O, Nakagawa A, Koya D, lizuka H. Pituitary apoplexy following gonadotropin-releasing hormone agonist administration with gonadotropin-secreting pituitary adenoma. J Clin Neurosci. 2015;22(3):601-3.

23. Brar KS, Garg MK. High altitude-induced pituitary apoplexy. Singapore Med J. 2012;53(6):e117-9.

24. Wildemberg LE, Neto LV, Niemeyer P, Gasparetto EL, Chimelli L, Gadelha MR. Association of dengue hemorrhagic fever with multiple risk factors for pituitary apoplexy. Endocr Pract. 2012;18(5):e97-e101.

25. Mura P, Cossu AP, Musu M, DE Giudici LM, Corda L, Zucca R, et al. Pituitary apoplexy after laparoscopic surgery: a case report. Eur Rev Med Phramacol Sci. 2014;18:3524-7.
26. Piantanida E, Gallo D, Lombardi V, Tanda ML, Lai A, Ghezzi F, et al. Pituitary apoplexy during pregnancy: a rare, but dangerous headache. J Endocrinol Invest. 2014;37(9):789-97.

27. Jahangiri A, Clark AJ, Han SJ, Kunwar S, Blevins LS Jr, Aghi MK. Socioeconomic factors associated with pituitary apoplexy. J Neurosurg. 2013;119(6):1432-6.

28. Bi WL, Dunn IF, Laws ER Jr. Pituitary apoplexy. Endocrine. 2015;48(1):69-75.

29. Briet C, Salenave S, Chanson P. Pituitary apoplexy. Endocrinol Metab Clin North Am. 2015;44(1):199-209.

30. Ayuk J, McGregor EJ, Mitchell RD, Gittoes NJ. Acute management of pituitary apoplexy-surgery or conservative management? Clin Endocrinol. 2004;61:747-52.

31. Briet C, Salenave S, Chanson P. Pituitary apoplexy. Endocrinol Metab Clin North Am. 2015;44(1):199-209.

32. Bills DC, Meyer FB, Laws ER Jr, Davis DH, Ebersold MJ, Scheithauer BW, et al. A retrospective analysis of pituitary apoplexy. Neurosurgery. 1993;33:602-9.

33. Maccagnan P, Macedo CL, Kayath MJ, Nogueira RG, Abucham J. Conservative management of pituitary apoplexy: a retrospective study. J Clin Endocrinol Metab. 1995;80:2190-7.

34. Randeva HS, Schoebel J, Byrne J, Esiri M, Adams CB, Wass JA. Classical pituitary apoplexy: clinical features, management and outcome. Clin Endocrinol. 1999;51:181-8.

35. Lubina A, Olchovsky D, Berezin M, Ram Z, Hadani M, Shimon I. Management of pituitary apoplexy: clinical experience with 40 patients. Acta Neurochir (Wien). 2005;147(2):151-7.

36. Bujawansa S, Thondam SK, Steele C, Cuthbertson DJ, Gilkes CE, Noonan $\mathrm{C}$, et al. Presentation, management and outcomes in acute pituitary apoplexy: a large single-centre experience from the United Kingdom. Clin Endocrinol (Oxf). 2014;80(3):419-24.

37. Jho DH, Biller BM, Agarwalla PK, Swearingen B. Pituitary apoplexy: large surgical series with grading system. World Neurosurg. 2014;82(5):781-90.

38. Singh TD, Valizadeh N, Meyer FB, Atkinson JL, Erickson D, Rabinstein AA. Management and outcomes of pituitary apoplexy. J Neurosurg. 2015 Apr 10:1-8.

39. Bonneville F, Cattin F, Marsot-Dupuch K, Dormont D, Bonneville JF, Chiras J. T1 Signal hyperintensity in the sellar region: spectrum of findings. Radiographics. 2006;26(1):93-113.

40. Boellis A, di Napoli A, Romano A, Bozzao A. Pituitary apoplexy: an update on clinical and imaging features. Insights Imaging. 2014;5(6):753-62. 